\title{
Evaluation of hepatoprotective activity of Hexafite in $D$-galactosamine hepatitis, antioxidant activity of the drug and its ingredients
}

\author{
(C) Ekaterina V. Ferubko, Anatoly A. Lapin* ${ }^{+}$ \\ Tamara D. Dargaeva, and Valery N. Zelenkov \\ All-Russian Scientific Research Institute of Medicinal and Aromatic Plants. \\ Greene St., 7. Moscow, 117216. Russia.E-mail: zelenkov-raen@mail.ru
}

\begin{abstract}
*Supervising author; ${ }^{+}$Corresponding author
Keywords: Hexafite multicomponent extract, experimental hepatitis, hepatoprotective activity, antioxidant activity, collection and incoming ingredients.
\end{abstract}

\begin{abstract}
The expansion of research to find sources for obtaining new effective and safe medicines of plant origin, including those used in gastroenterological practice, is a pressing task of medical science, considering that the range of medicinal plant drugs used in practical health care is more than $40 \%$. The results of the biochemical study of the hepatoprotective and choleretic activities of a Hexafite multicomponent extract obtaining from following types of raw materials: flowers of Helichrysum arenarium L. and Tanacetum vulgare L., fruits of Rosa sp., leaves of Urtica dioica L. and Mentha piperita L. and radices of Glycyrrhiza glabra L. were received. It is established that Hexafite per os administration of dose of $250 \mathrm{mg} / \mathrm{kg}$ to nonlinear white rats with $D$-galactozamine induced liver injury has hepatoprotective and choleretic effects, exceeding Allocholum effect by some data. Pharmacotherapeutic effect of the extract in model of liver injury is due to the presence in it of a complex of biologically active substances, primarily compounds of phenolic nature. The inhibitory effect of Hexafite on free radical oxidation of lipids, stabilization of the biological membranes of liver cells with a subsequent increase in the functional activity of the liver is provided due to their dominant content. The obtained research results argue the expediency of the use of Hexafite containing biologically active substances of a phenolic nature in the prevention and treatment of liver diseases. It is shown that the collection of bile action and the plants included in it have antioxidant activity in vitro. The experiment revealed a synergistic effect on the manifestation of the total antioxidant activity of the collection.
\end{abstract}

\section{References}

[1] P.-N.B. Lubsandorzhieva. Development and standardization of phytodetic agents for the treatment and prevention of digestive diseases. Ulan-Ude: Publishing House of the BSC SB RAS. 2016. 280p. (russian)

[2] Patent 2700681 of the Russian Federation. Ferubko E.V., Nikolaev S.M., Dargaeva M. Agent possessing choleretic activity and method of its preparation. Patent of the Russian Federation No. 2700681, publ. 19.09.2019, Bul. No.26, priority with 13.06.2019. (russian)

[3] A.I. Vengerovsky, I.V. Markova, A.S. Saratikov. Methodological guidelines for the study of hepatoprotective activity of pharmacological substances. Guidelines for the experimental (preclinical) study of novel pharmacological substances. Moscow: Medicine. 2005. P.683-691. (russian)

[4] R.A. Temirbulates, E.I. Seleznev. Method of increasing the intensity of free radical oxidation of lipidcontaining blood components and its diagnostic value. Lab case. 1981. No.4. P.209-211. (russian)

[5] I.D. Steel. Method of determining the dienic conjugation of unsatis meteish higher fatty acids. Modern methods in biochemistry. 1977. P.66-68. (russian)

[6] J.I. Karbach. The quantitative definition of bile acids in bile and blood using the chromatographic method. Biochemistry. 1961. No.2. P.305-307. (russian)

[7] V.P. Borovikov. Popular introduction to modern data analysis in the system STATISTICA. Moscow: Hottine. Telecom. 2014. 288p. (russian)

[8] A.A. Lapin, N.G. Romanova, V.N. Zelenkov. Use of galvanostatic pendantometry method in determining the antioxidant activity of various types of biological raw materials and products of their processing. Moscow: MSHA, K.A. Timiryazeva. 2011. 197p. (russian)

[9] S.M. Nikolaev. Phytopharmacology and phytopharmacoroprophiliacy diseases. Ulan-Ude: BSU. 2012. 286p. (russian) 
EVALUATION OF HEPATOPROTECTIVE ACTIVITY OF HEXAFITE IN D-GALACTOSAMINE HEPATITIS..._ 70-76

[10] A.A. Lapin, I.G. Garifullin, and V.N. Zelenkov. Biochemical study of hepatoprotective collection of plant origin. Butlerov Communications. 2019. Vol.59. No.7. P.134-141. DOI: 10.37952/ROI-jbc-01/1959-7-134]

[11] A.A. Lapin, I.G. Garifullin, S.D. Litvinov. Antioxidant properties of hepatoprotective collection. Bulletin of the medical institute "REAVIZ": rehabilitation, doctor and health. 2019. No.5(41). P.202207. (russian)

[12] E.V. Ferubko, V.N. Zelenkov, A.A. Lapin, and T.D. Dargaeva. Study of the antioxidant activity of plant harvest with antiulcer action and its components. Butlerov Communications. 2019. Vol.60. No.10. P.6066. DOI: 10.37952/ROI-jbc-01/19-60-10-60

[13] A.A. Lapin, and V.N. Zelenkov. The use of vyazolistnogo labaznik (Filipendula ulmaria (L.) Maxim) to increase the antioxidant activity of hepatoprotective collection of plant origin. Butlerov Communications. 2020. Vol.61. No.3. P.112-119. DOI: 10.37952/ROI-jbc-01/20-61-3-112

[14] A.A. Lapin, I.G. Garifullin, S.D. Litvinov, V.N. Zelenkov. Antioxidant properties of aqueous media with molecular hydrogen and their use in eco-friendly medicine. Bulletin of Medical Institute Reaviz. 2020. No.2. P.13-20. (russian) 